\title{
Assessment of Hemophilia and Associated Risk Factors at Rural Area of Sindh Pakistan
}

\author{
Arslan Ahmer ${ }^{1, *}$, Gulshan Ali Memon ${ }^{2}$, Muhammad Saleh Khaskheli ${ }^{3}$, Khan Muhammad Bullo ${ }^{4}$, Tahseen \\ Ahmed', Niaz Hussain Jamali' \\ ${ }^{1}$ Institute of Pharmaceutical Sciences, People's University of Medical and Health Sciences, Nawabshah, \\ Pakistan. \\ ${ }^{2}$ Department of Surgery, People's University of Medical and Health Sciences for Women,Nawabshah, Sindh, \\ Pakistan. \\ ${ }^{3}$ Department of Anesthesiology, People's University of Medical and Health Sciences for Women, Nawabshah, \\ Sindh, Pakistan. \\ ${ }^{4}$ Registrar, People's University of Medical and Health Sciences for Women, Nawabshah, Sindh, Pakistan.
}

Authors' Contributions

1 Conception \& Study Design, Data Collection, Data Analysis, Drafting, Critical Review.

2 Data Analysis, Critical Review, Drafting.

3 Data Analysis, Critical Review.

4,5 and 6 Critical Review.

\section{Acknowledgement}

Authors are thankful to the population of Sindh for providing the research data.

\section{Article info.}

Received: September 7, 2019

Accepted: June 24, 2020

Funding Source: Nil

Conflict of Interest: Nil

Cite this article: Ahmer A, Memon GA, Khaskheli MS, Bullo KM, Ahmed T, Jamali NH. Assessment of Hemophilia and Associated Risk Factors at Rural Area of Sindh Pakistan RADS J Pharm Pharm Sci. 2020; 8(2):68-73.

*Address of Correspondence Author: arslan.ahmer@gmail.com

\section{ABSTRACT}

Background: Hemophilia is a genetic disorder related to blood, in which the blood is impotent to clot the draining due to paucity of blood clotting factor.

Objective: The dramatic theme of this research was to evaluate the knowledge skills about hemophilia in healthy individuals and cradle regarding familiarity of this ailment was also evaluated.

Methods: Crossectional randomized research was conducted on 274 study subject's normal population of rural areas of Sindh and frequent questions apropos cognizance of this disease were probed from all participants and SPSS software was used for the analysis of the data.

Results: From the given data, it was estimated that $59 \%$ of the population were familiar with hemophilia, whereas $36 \%$ study subjects had no idea about this disease, feminine gender were more familiar with risk factors and people who had more knowledge about hemophilia were graduate in qualification. Chi Square value was found 0.001 .

Conclusion: It was concluded from the research that there should be promotional seminars should be conducted from health care providers regarding hemophilia and its risk factors.

Keywords: Hemophilia, Chi-Square, Blood Clotting factors.

\section{INTRODUCTION}

X-chromosomes are the main cause for creating the diseases associated with genetic and hereditary such as in hemophilia, absence of blood clotting factor are also associated with X-chromosomes [1]. In this disease blood of any individual is unable to clot the flow of blood in the case of any injury [2]. There are some varieties of hemophilia that can be elaborated as Hemophilia A that occurs due to deficiency of VIII factors in the blood whereas Hemophilia B is caused by deficit of IX factor. [3] The incidence of Hemophilic $A$ is very common as compare to Hemophilic $B$ but the cases of each types are very rare such as 
Hemophilic $A$ found in one among five thousand in new child birth whereas hemophilic $B$ is very rare and unable to find in normal situations [4,5]. Beside all these risk factors few another cases of hemophilia are reported such as Hemophilia C and Para-hemophilia that are reported with the deficiencies of intrinsic factor XI and V respectively [6]. Para-hemophilia is sometime caused by any injury (acquired) and sometime due to genetic mutations [7]. It is estimated globally that there are approximately 4 lakhs patients are reported with various type of hemophilia [8]. History related to this infrequent disease was quite ancient as very $1^{\text {st }}$ case of this disease was reported almost 10 century ago in the period of Abulcasis, then it was elaborated by a Physician named Dr. John Conrad Otto in 1803 as it was considered that effected families with hemophilia were termed as Bleeders [9, 10]. The life of hemophilic patients totally depends upon the medication usage, if proper medication is not given to them they may not survived normally and faced to death before the age of adulthood and it was considered that patients with hemophilia had possible 10 years less age than the healthy one [11]. $30 \%$ of hemophilia patients didn't need any therapy for the management of bleeding because of various reason and $8 \%$ hemophilic person face the fatal bleeding including GIT, Intracranial and Retro-peritoneal bleeding [12, 13]. Clinically it can be categorized from minor illness to life threatening disorder because of alteration in bleeding time [14]. AHA (Acquired Hemophilic A) patients had almost same co-morbidities and same therapy as of antiplatelets so it seems to be similar in accordance with clinical point of view, they should need specified therapy [15]. According to various research conducted on the hemophilia it was noticed that genetic disorder can be managed or altered with specified hemostasis along with blood coagulations. There is no any specific therapy available for the management of AHA but supplementary therapy was given to them in order to save them for life threatening problem and management may include Porcine VIII factor and Recombinant VII a factor [16]. Rough idea regarding this disease may include almost 18 thousand of patients were reported with hemophilia in Pakistan and from them only $8-10 \%$ of patients were facilitated with medicines and remaining patients were not diagnosed properly and not treated accordingly. The major theme of this research to assess the awareness of common population concerning with hemophilia so cross-sectional study was conducted to collect the data.

\section{MATERIALS AND METHODS}

\section{Study Area}

The research was conducted at rural areas of Sindh and normal healthy population was used for analysis.

\section{Study Period}

This research was conducted for the period of 06 months from July 2018 to December 2018.

\section{Participants}

Crossectional survey was conducted for probing the acquaintance of healthy individuals regarding hemophilia and apart from data, all individuals were having various qualification levels. Total 274 study subjects were included in this study and a questionnaire was filled from each subject to collect the data.

\section{Questionnaire}

The questionnaire was categorized into 02 different parts initial part consist of demographic data such as Gender, Age Qualification whereas another portion totally based on clinical data regarding Disease knowledge, treatment availability and various related factors.

\section{Statistical Analysis}

SPSS version 24.00 was used and various analytical test were conducted as chi-square test, descriptive statistics, frequency and percentage skills were used.

\section{RESULT}

According to demographic data, $52.9 \%$ were females whereas $47.1 \%$ were males. As mentioned in Table 1, beside this all participants were having various age groups as mentioned in Table 2 and according to age wise distribution all participants were divided in 06 different groups.

\section{Table 1. Gender wise distribution of study subjects.}

\begin{tabular}{|c|c|c|c|c|c|}
\hline \multicolumn{2}{|c|}{} & Frequency & Percent & Valid Percent & Cumulative Percent \\
\hline \multirow{3}{*}{ Valid } & Female & 145 & 52.9 & 52.9 & 52.9 \\
\cline { 2 - 6 } & Male & 129 & 47.1 & 47.1 & 100.0 \\
\cline { 2 - 6 } & Total & 274 & 100.0 & 100.0 & \\
\hline
\end{tabular}


Table 2. Age wise distribution of study subjects.

\begin{tabular}{|c|c|c|c|c|c|}
\hline \multicolumn{2}{|c|}{} & Frequency & Percent & Valid Percent & $\begin{array}{c}\text { Cumulative } \\
\text { Percent }\end{array}$ \\
\hline \multirow{7}{*}{ Valid } & Below 20 years & 6 & 2.2 & 2.2 & 2.2 \\
\cline { 2 - 6 } & $21-26$ years & 118 & 43.1 & 43.1 & 45.3 \\
\cline { 2 - 6 } & $27-33$ years & 113 & 41.2 & 41.2 & 86.5 \\
\cline { 2 - 6 } & $34-40$ years & 18 & 6.6 & 6.6 & 93.1 \\
\cline { 2 - 6 } & $41-47$ years & 14 & 5.1 & 5.1 & 98.2 \\
\cline { 2 - 6 } & 47 to onwards & 5 & 1.8 & 1.8 & 100.0 \\
\cline { 2 - 6 } & Total & 274 & 100.0 & 100.0 & \\
\hline
\end{tabular}

Table 3. According to Qualification of study subjects

\begin{tabular}{|c|c|c|c|c|c|}
\hline \multicolumn{2}{|c|}{} & Frequency & Percent & Valid Percent & $\begin{array}{c}\text { Cumulative } \\
\text { Percent }\end{array}$ \\
\hline \multirow{4}{*}{ Valid } & Primary & 13 & 4.7 & 4.7 & 4.7 \\
\cline { 2 - 6 } & Secondary & 46 & 16.8 & 16.8 & 21.5 \\
\cline { 2 - 6 } & Intermediate & 169 & 61.7 & 61.7 & 83.2 \\
\cline { 2 - 6 } & Graduate & 46 & 16.8 & 16.8 & 100.0 \\
\cline { 2 - 6 } & Total & 274 & 100.0 & 100.0 & \\
\hline
\end{tabular}

Table 4. Information regarding the Hemophilia as a Blood disorder.

\begin{tabular}{|c|c|c|c|c|c|}
\hline \multicolumn{2}{|c|}{} & Frequency & Percent & Valid Percent & $\begin{array}{c}\text { Cumulative } \\
\text { Percent }\end{array}$ \\
\hline \multirow{3}{*}{ Valid } & Yes & 86 & 31.4 & 31.4 & 31.4 \\
\cline { 2 - 6 } & No & 61 & 22.3 & 22.3 & 53.6 \\
\cline { 2 - 6 } & Don't Know & 127 & 46.4 & 46.4 & 100.0 \\
\cline { 2 - 6 } & Total & 274 & 100.0 & 100.0 & \\
\hline
\end{tabular}

As for as qualification is concern, study subjects were divided in various groups such as Primary $4.7 \%$, Secondary $16.8 \%$, Intermediate $61.7 \%$ and Graduate $16.8 \%$. As mentioned in Table 3 . The information regarding knowledge of hemophilia was collected from study subjects, 86 study participants were having knowledge of this disease,whereas 127 study subjects were commented that they didn't have idea about this disease as mentioned in Table 4.
Source of information regarding the Hemophilia among the participants and their qualification level is described in Figure. 1.

The sources of knowledge regarding hemophilia was collected from study subjects and the sources were academic books $17.9 \%$, Internet or TV $15 / 3 \%$, News Paper $17.2 \%$, leaflet of hemophilia $49.3 \%$ as described in Table 5. 


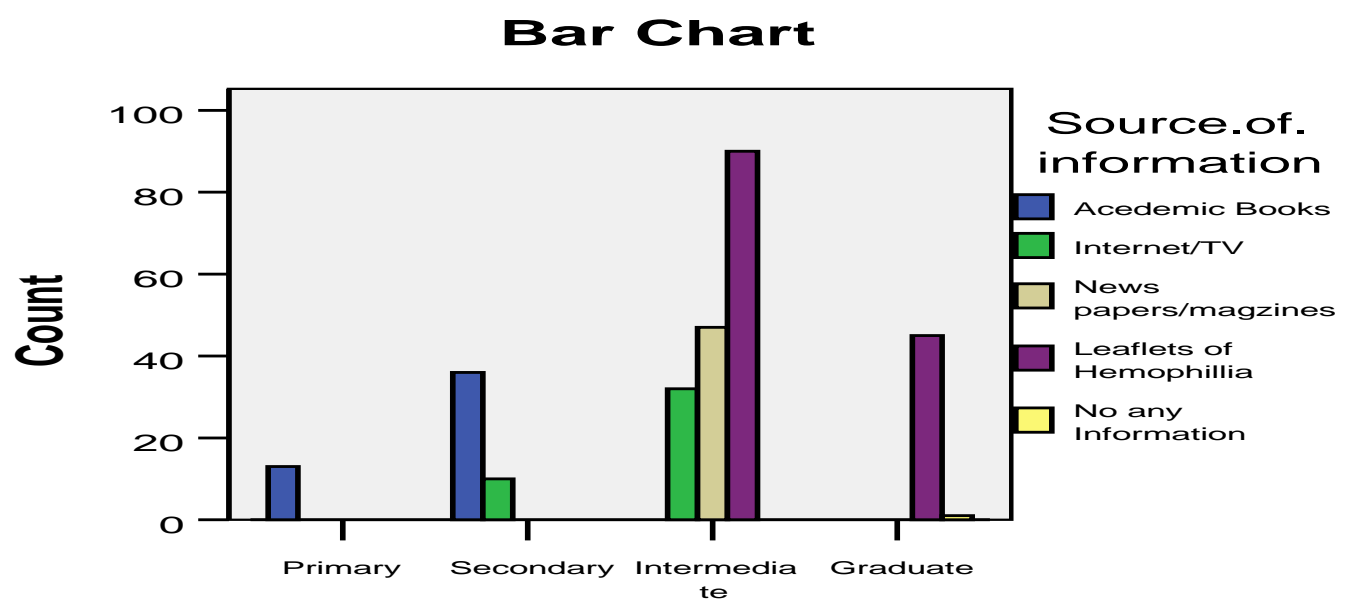

Qualification

Figure 1. Source of information regarding Hemophilia among participants and their qualification level.

Table 5. Source of Information regarding Hemophilia among study subjects.

\begin{tabular}{|c|c|c|c|c|c|}
\hline \multicolumn{2}{|c|}{} & Frequency & Percent & Valid Percent & $\begin{array}{c}\text { Cumulative } \\
\text { Percent }\end{array}$ \\
\hline \multirow{7}{*}{ Valid } & Academic Books & 49 & 17.9 & 17.9 & 17.9 \\
\cline { 2 - 6 } & Internet/TV & 42 & 15.3 & 15.3 & 33.2 \\
\cline { 2 - 6 } & News Paper/magazine & 47 & 17.2 & 17.2 & 50.4 \\
\cline { 2 - 6 } & Leaflets of Hemophilia & 135 & 49.3 & 49.3 & 99.6 \\
\cline { 2 - 6 } & No any Information & 1 & .4 & .4 & 100.0 \\
\cline { 2 - 6 } & Total & 274 & 100.0 & 100.0 & \\
\hline
\end{tabular}

Table 6. Gender wise distribution of disease.

\begin{tabular}{|c|c|c|c|c|c|}
\hline \multicolumn{2}{|c|}{} & Frequency & Percent & Valid Percent & $\begin{array}{c}\text { Cumulative } \\
\text { Percent }\end{array}$ \\
\hline \multirow{3}{*}{ Valid } & Males & 143 & 52.2 & 52.2 & 52.2 \\
\cline { 2 - 6 } & Females & 131 & 47.8 & 47.8 & 100.0 \\
\cline { 2 - 6 } & Total & 274 & 100.0 & 100.0 & \\
\hline
\end{tabular}

As for as gender was concerned, the study subjects were categorized in to two sections, 143 study subjects were males and 131 were females as described in Table 6.

121 study subjects were have idea that hemophilia was genetic disorder, according to $16.8 \%$ of participants that this disease was not a genetic disorder whereas 107 study subjects didn't have idea disease. All data was mentioned accordingly in Table 7. As far as availability of treatment was evaluated in all research groups and they were facilitated with the answer of Yes, No or Don't Know and the data regarding each answer was described in Table 8. 
Table 7. Knowledge of participants that hemophilia is Genetic disorder.

\begin{tabular}{|c|c|c|c|c|c|}
\hline \multicolumn{2}{|c|}{} & Frequency & Percent & Valid Percent & $\begin{array}{c}\text { Cumulative } \\
\text { Percent }\end{array}$ \\
\hline \multirow{3}{*}{ Valid } & Yes & 121 & 44.2 & 44.2 & 44.2 \\
\cline { 2 - 6 } & No & 46 & 16.8 & 16.8 & 60.9 \\
\cline { 2 - 6 } & Don't Know & 107 & 39.1 & 39.1 & 100.0 \\
\cline { 2 - 6 } & Total & 274 & 100.0 & 100.0 & \\
\hline
\end{tabular}

Table 8. Knowledge of participants regarding availably of treatment of hemophilia.

\begin{tabular}{|c|c|c|c|c|c|}
\hline \multicolumn{2}{|c|}{} & Frequency & Percent & Valid Percent & $\begin{array}{c}\text { Cumulative } \\
\text { Percent }\end{array}$ \\
\hline \multirow{4}{*}{ Valid } & Yes & 156 & 56.9 & 56.9 & 56.9 \\
\cline { 2 - 6 } & No & 43 & 15.7 & 15.7 & 72.6 \\
\cline { 2 - 6 } & Don't Know & 75 & 27.4 & 27.4 & 100.0 \\
\cline { 2 - 6 } & Total & 274 & 100.0 & 100.0 & \\
\hline
\end{tabular}

\section{DISCUSSION}

This disorder belongs to blood and it is not common disorder, with reference to population, disease occur very rare but the patients suffer more in accordance with economical value and physical stress. Due to very less number of patients of hemophilia, no any effective work had done in ancient period as many work had been done on various other disease and related complications. It was observed that due to less study of hemophilia the patients were left to die because of unknown pathophysiology of disorder. The milestone had been achieved since last two decades when the medical field got improvement that reduces the death rates and it was noticed that

hemophilia was more common among Males due to presences of excessive inheritance of $X$ chromosomes. There was no any specific race or ethnicity related to this disease and according to survey conducted in Pakistan that there is very minute population of hemophilia registered in Hemophilic society, so it is prime responsibility of the family members of that disease to get registered their patients to specific society to get rid of this disease and the number of patients \& their accountability regarding this fatal disease can be managed accordingly.

\section{CONCLUSION}

Hemophilia is very uncommon disease related to genetic disorder and its pathophysiology along with its management is still unknown to majority of patients suffering from this fatal disease. The rates of disease are very high among the hemophilic patient that result damage of joints \& hemorrhage. The major theme of this disease to evaluate the knowledge level regarding hemophilia in normal population of the rural areas of Sindh and it was clearly recognized that majority of people were unknown about this disease as its symptoms \& treatment. It was noticed that there should be seminar conducted by Health Care Professionals (HCPs) to initiate the awareness regarding hemophilia among rural area population of Sindh.

\section{REFERENCES}

1. Morrison AE, Ludlam CA, Kessler C. Use of porcine factor VIII in the treatment of patients with acquired hemophilia. Blood. 1993; 81(6):1513-20. doi.org/10.1182/blood.V81.6.1513.1513

2. Hay CR, Negrier C, Ludlam CA. The treatment of bleeding in acquired haemophilia with recombinant factor VIla: a multicentre study. Thromb Haemost. 1997; 78(1): 1463-7.

3. Rogers GL, Herzog RW. Gene therapy for hemophilia. Frontiers in bioscience (Landmark edition). 2015; 20:556-603 
4. Wynbrandt J, Ludman MD. The encyclopedia of genetic disorders and birth defects $3^{\text {rd }}$ Ed. Infobase Publishing 2010.

5. Thalji N, Camire RM. Parahemophilia: new insights into factor $v$ deficiency. InSeminars in thrombosis and hemostasis. Thieme Medical Publishers. 2013; 39(6):607-12.

Doi.org/10.1055/s-0033-1349224.

6. "Case of the Week 175". University of Utah Medical Library. Archived from the original on 2011.

http://web.archive.org/web/20110519140955/http:// ibrary.med.utah.edu/WebPath/COW/COW175.html

7. Nilsson IM. Blödarsjuka--förr och nu [Haemophilia-then and now]. Sydsven Medicinhist Sallsk Arsskr 1994; 31: 33-52. PMID: 11640407.

8. Roosendaal G, Lafeber F. Prophylactic treatment for prevention of joint disease in hemophilia-cost versus benefit. N Engl J Med 2007; 357(6): 60305.

\section{doi: 10.1056/NEJMe078098}

9. Collins PW, Hirsch S, Baglin TP. Acquired hemophilia $A$ in the United Kingdom: a 2-year national surveillance study by the United Kingdom Haemophilia Centre Doctors' Organisation. Blood 2007; 109(5): 1870-77. doi: 10.1182/blood-200606-029850.

10. Morrison AE, Ludlam CA. Acquired haemophilia and its management. $\mathrm{Br} \mathrm{J}$ Haematology 1995; 89(2): 231-36.

doi: 10.1111/j.1365-2141.1995.tb03294.x.
11. Lottenberg R, Kentro TB, Kitchens CS. Acquired hemophilia: a natural history study of 16 patients with factor VIII inhibitors receiving little or no therapy. Arch Intern Med. 1987; 147(6): 1077-81. doi: 10.1001/archinte.147.6.1077.

12. Grunewal M, Beneke H, Guthner C, Germowitz A, Brommer A, Griesshammer M. Acquired haemophilia: experiences with a standardized approach. Haemophilia 2001; 7(2): 164-69. doi.org/10.1046/j.1365-2516.2001.00488.x.

13. Green D. The management of acquired haemophilia. Haemophilia 2006; 12 (s5): 32-36. doi.org/10.1111/j.1365-2516.2006.01383.x.

14. Gailani D, Renne T. Intrinsic pathway of coagulation and arterial thrombosis. Arterioscl Throm Vas 2007; 27(12): 2507-13. doi: 10.1161/ATVBAHA.107.155952.

15. Huth-Kühne A, Baudo F, Collins P. International recommendations on the diagnosis and treatment of patients with acquired hemophilia A. Haematologica. 2009; 94(4):566-75. doi.org/10.3324/haematol.2008.001743.

16. Mackman N, Tilley RE, Key NS. Role of the extrinsic pathway of blood coagulation in hemostasis and thrombosis. Arterioscl Throm Vas 2007; 27(8): 1687-93. doi.org/10.1161/ATVBAHA.107.141911. 